\section{New problems in testing for Huntington's disease: the issue of intermediate and reduced penetrance alleles}

EDITOR-Huntington's disease (HD) is an autosomal dominant, progressive, incurable neuropsychiatric disorder, characterised by chorea, changes in personality, mood, and behaviour, and dementia. Because the mean age at onset is 40 years (range 5 to 70 years), the risk for a healthy young adult with an affected parent will remain nearly $50 \%$, making decisions about the future and family planning difficult. ${ }^{2}$ After the localisation of the gene to chromosome 4 p16.3 in 1983, predictive testing by linkage analysis became available for subjects at risk for $\mathrm{HD}^{3}$ and was shown to have potential benefits. ${ }^{4}$ When the mutation in the HD gene was identified in $1993,{ }^{5}$ predictive testing became technically simpler, reliable, and available for everyone at risk. $\mathrm{HD}$, like other neurodegenerative disorders (for example, SCA1, 2, 3, 6, and 7, DRPLA, and SBMA), is caused by an expanded CAG repeat. The wild type allele has six to 35 copies but affected subjects have between 36 and 121 repeats. ${ }^{67}$ The HD and normal range have quite distinct peaks but the tails of both curves are close to each other. As in SCA1 and 2 (and as opposed to SCA3 and 6, SBMA, and DRPLA), there is no gap between normal and disease ranges in HD and reduced penetrance is found in the lower range of the disease repeat. The normal repeat segregates simply and stably as a polymorphic locus, but the disease repeat size tends to increase and occasionally decrease in successive generations. ${ }^{8}$ The limits of the CAG repeat size in the $\mathrm{HD}$ gene have been redefined, ${ }^{9}$ based on the total number of normal and symptomatic subjects assessed.

A normal repeat, with less than 27 repeats, has never been associated with a HD phenotype, nor has it shown instability resulting in a HD allele in offspring. ${ }^{9-11}$

An intermediate repeat, with 27 to 35 repeats, has not been associated with a HD phenotype, ${ }^{67}$ but has shown instability ${ }^{12-14}$ and is found in $1.5^{6}$ to $1.9 \%{ }^{15}$ of the general population. For offspring of an intermediate allele carrier, there is a risk of inheriting more than 26 repeats and a small risk that transmission might result in a HD allele with or without penetrance. ${ }^{5}{ }^{16-18}$ The risk of expansion depends on the sex of the transmitting person, the repeat size, the level of mosaicism in sperm, if the intermediate allele is on a HD haplotype or if it is identified in a new mutation family or in the general population, and other, as yet unknown factors. ${ }^{12} 1920$ Risk estimates for expansion of an intermediate allele to 36 or more repeats in the offspring of male carriers vary between 2 and $10 \% .{ }^{14}{ }^{15}$ Expansions of intermediate alleles to 36 or more repeats in female carriers of intermediate alleles has not been described; their risk seems to be much smaller than for male carriers. Expansions of intermediate alleles into the pathological range have also been described in Friedreich's ataxia, ${ }^{21}$ myotonic dystrophy, ${ }^{22} \mathrm{SCA} 7,{ }^{23}$ and fragile X syndrome. ${ }^{24}$

A disease repeat with reduced penetrance, with 36 to 39 repeats, has been associated with clinically and pathologically confirmed HD, although the HD phenotype is not always penetrant, with increasing penetrance possibly associated with increasing repeat length. ${ }^{6725-27}$ Penetrance of 36 to 39 repeat alleles may be higher in persons with confirmed ancestry of HD than those from collateral branches with new mutations. ${ }^{15}$ Penetrance is also dependent on the expression of the disease in the parent with the expanded repeat, but reliable empirical penetrance risks are not yet available.

A disease repeat, with 40 or more repeats, is associated with Huntington pathology. Higher repeat sizes are associated with a younger age at onset. ${ }^{27}$

This evolving knowledge about genotype-phenotype correlation in HD has made genetic counselling in a small number more complicated. We have observed unexpected test results, specific psychological problems like feelings of guilt and reproach, and uncertainties about the risk for HD for test applicants, their offspring, and relatives. Consequently, new ethical questions have arisen. The international guidelines ${ }^{28}$ do not yet address these new problems. Also, genetic diagnostic services are in the process of collecting and reporting their experience with expansions of intermediate alleles into the pathological range in $\mathrm{HD}$ and other trinucleotide repeat diseases. Here, we present selected cases, illustrating the new problems encountered in the test procedures of different categories of subjects with repeats between 27 and 39 and the number of subjects observed in these categories. The resulting uncertainties in risk and prediction are outlined and provisional guidelines for counselling carriers of intermediate and reduced penetrance alleles are formulated.

In The Netherlands the estimated prevalence of $\mathrm{HD}$ is 6.5:100 000, based on the number of living affected subjects, recorded at the Leiden Roster for HD. Together, at least 3115 subjects at $50 \%$ risk were registered. Test applicants were counselled in the Departments of Clinical Genetics in Leiden and Rotterdam between 1993 and 1998. A structured predictive testing procedure for HD, according to the international guidelines, ${ }^{28}$ was introduced in 1987 in Leiden ${ }^{29}$ and after 1993 in the other Departments of Clinical Genetics. In counselling, we used approximate risk figures for intermediate allele carriers based on the best estimate of $<1 \%$ to develop HD and $\leqslant 1 \%$ risk for expansion to more than 36 repeats for children of female carriers and 5\% for male carriers. DNA analysis for HD in The Netherlands is centralised in Leiden. Differences were analysed using a chi-square test and $\mathrm{p}=0.05$ was the criterion for statistical significance.

In our series, we could discern five categories of subjects with intermediate or reduced penetrance alleles (table 1), depending on the family structure, test results, test indication, and status of the test applicant, each with its own counselling issues, as shown in the selected case descriptions (fig 1).

Category 1. Symptomatic test applicants inheriting a reduced penetrance allele on the HD haplotype. A man requested testing for HD because he wished to inform his daughter as she had entered adulthood. His mother had died at the age of 53 years, having possibly had HD related symptoms. Neuropathological study of her brain did not confirm HD, nor did later re-evaluation when her brother, with onset of HD at 43 years and a reduced penetrance repeat (39), died at the age of 56. His maternal grandparents and father had died young of unrelated causes. The man showed alleles with 28 and 37 repeats. It was concluded that the man had 
a risk of developing $\mathrm{HD}$ with the possibility of reduced penetrance, and that his daughter, in addition to the $50 \%$ risk for the reduced penetrance allele, had a risk of inheriting the (possibly expanded) intermediate allele.

Category 2. (A) symptomatic test applicants inheriting an intermediate or reduced penetrance allele from unaffected parent (no family history). Three sibs applied for predictive testing to relieve the uncertainty about their genetic status. Their father and dead grandfather were diagnosed with HD. Because of a poor relationship, the applicants did not discuss the test with their mother. The mother showed psychiatric symptoms, but no chorea; she had no known family history of HD. All three applicants showed one allele well within the affected range together with a reduced penetrance allele (36 repeats). This indicated that the mother might be affected, but she refused either a neurological

Table 1 Frequencies and mean repeat length ( $\left(^{*}\right)$ of intermediate (IA) and reduced penetrance (RP) alleles in symptomatic ( $\left.n=659\right)$ and predictive $(n=442)$ test applicants in Leiden and Rotterdam (1993-1998) in the five different categories of subjects with intermediate or reduced penetrance alleles

\begin{tabular}{|c|c|c|c|c|c|c|}
\hline \multirow[b]{2}{*}{ Test outcome } & \multicolumn{6}{|c|}{ Categories of subjects with $I A / R P$ allele } \\
\hline & $\begin{array}{l}\text { (1) Symptomatic } \\
\text { test applicants } \\
\text { inheriting RP } \\
\text { allele on } H D \\
\text { haplotype }\end{array}$ & $\begin{array}{l}\text { (2) (A) symptomatic } \\
\text { test applicants } \\
\text { inheriting IA/RP } \\
\text { allele from unaffected } \\
\text { parent (no family } \\
\text { history) }\end{array}$ & $\begin{array}{l}\text { (3) Asymptomatic } \\
\text { test applicants } \\
\text { inheriting IA/RP } \\
\text { allele on } H D \\
\text { haplotype }\end{array}$ & $\begin{array}{l}\text { (4) Asymptomatic } \\
\text { test applicants who } \\
\text { are relatives of } \\
\text { newly identified } \\
\text { HD patient (no } \\
\text { family history) }\end{array}$ & $\begin{array}{l}\text { (5) Asymptomatic } \\
\text { partners (no family } \\
\text { history) of carriers, } \\
\text { tested as a control for } \\
\text { prenatal testing }\end{array}$ & Total \\
\hline IA allele (with disease allele) in symptomatic subject & - & $17(29)^{\star}$ & - & - & - & 17 \\
\hline $\mathrm{RP}$ allele in symptomatic subject & $16(39)^{\star}$ & 0 & - & - & - & 16 \\
\hline IA allele in asymptomatic subject & - & $16(29)^{\star}$ & $2(34)^{\star}$ & $6(32)^{\star}$ & $2(29)^{\star}$ & 26 \\
\hline $\mathrm{RP}$ allele in asymptomatic subject & - & $3(36)^{\star}$ & $9(39)^{\star}$ & 0 & 0 & 12 \\
\hline Total & 16 & 36 & 11 & 6 & 2 & 71 \\
\hline
\end{tabular}

Category/case 1:

symptomatic test applicant

inheriting RP allele on

HD haplotype

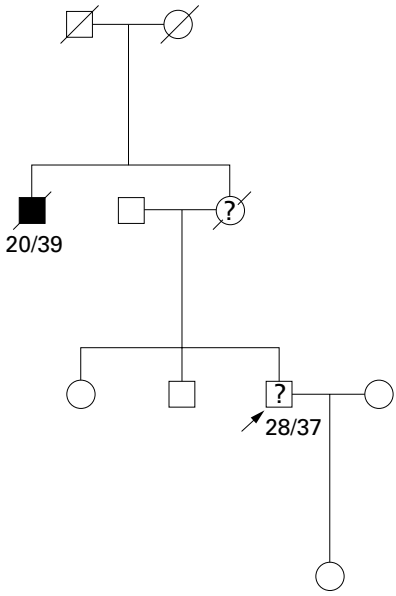

Category/case 2:

(a) symptomatic test applicants inheriting RP allele from unaffected parent (no family history)

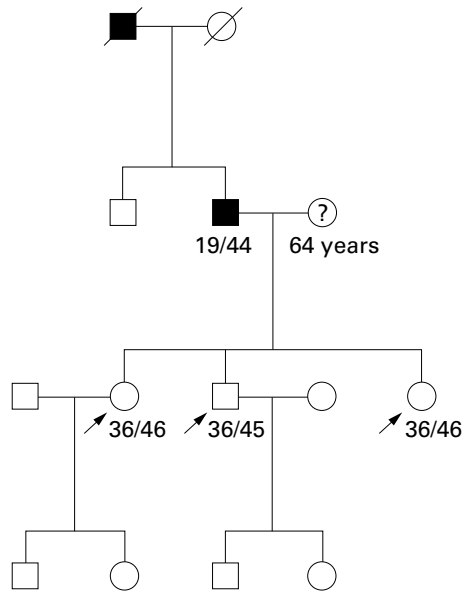

Category/case 4: asymptomatic test applicants asymptomatic partner (no family who are relatives of newly history) of carrier who is tested identified HD patient (no family history)

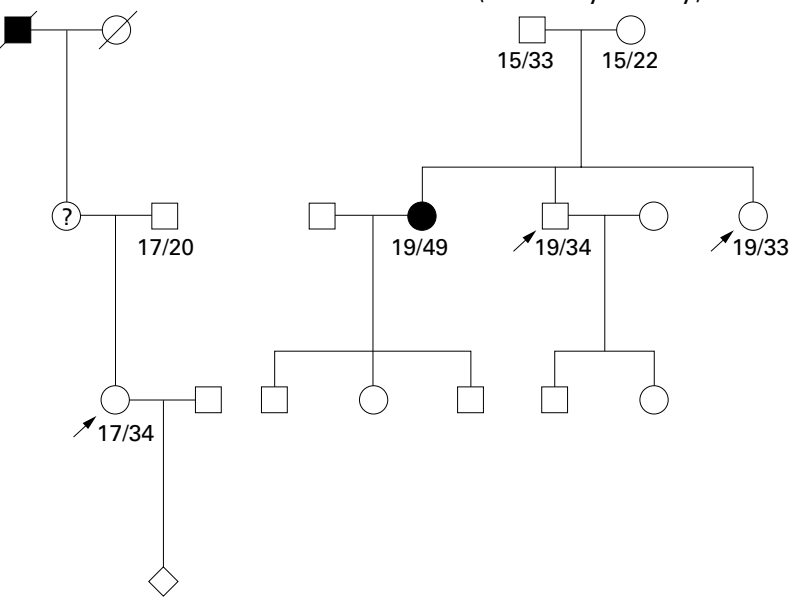
as a control for prenatal testing

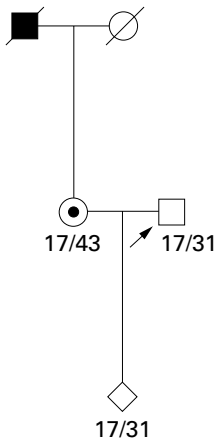

Figure 1 Pedigrees of test applicants for Huntington's disease in the five different categories of subjects with 27-39 repeats. (The numbers in the pedigrees refer to the $C A G$ repeat sizes in the $H D$ gene.) 
assessment or DNA analysis. The applicants realised that the risk for present and future children might be higher than $50 \%$. The two applicants with children decided to refrain from having further children. The one without children is considering prenatal diagnosis, accepting a fetus with 36 repeats, hoping for the possibility of reduced penetrance. The applicants might be homozygous, which does not affect the clinical features or age at onset. ${ }^{30}$ There is also a risk for relatives from the "unaffected" family from the mother.

Category 3. Asymptomatic test applicants inheriting intermediate or reduced penetrance allele on HD haplotype. A young female requested predictive testing because she wanted to know her genetic status before starting a family. A maternal grandparent had pathologically confirmed HD, her family was known in the Leiden Roster, and a disease repeat was found in a distant relative. Her mother did not want to discuss HD, because she found it a disgrace to the family and refused testing. The daughter described the mother as probably affected. DNA analysis in the daughter showed a normal (17) and an intermediate (34) repeat. The father showed normal alleles. We mentioned a risk of $<1 \%$ for the applicant to develop HD and a risk of about $1 \%$ for expansion into a HD allele for her future children. The applicant was relieved she had not inherited a disease repeat, but decided to use the option of prenatal diagnosis. She intended to terminate a pregnancy if $\geqslant 36$ repeats were identified. The prenatal test in her first pregnancy resulted in normal repeats.

Category 4. Asymptomatic test applicants who are relatives of newly identified HD patient (no family history). An adult woman had symptoms of HD and was found to have a disease repeat. Her parents were healthy (73 and 78 years) and the father showed an intermediate (33 repeats) allele. The patient's brother and sister, unexpectedly confronted with a possible risk for themselves and their offspring, applied for testing. Both of them showed an intermediate allele of 33 and 34 repeats, respectively, derived from their father. Their personal risk of developing HD was estimated as $<1 \%$, and the risk for children of the sister approximately $\leqslant 1 \%$ and of the brother $5 \%$. Prenatal testing was discussed with them. We suggested that they should inform relatives of the result and related consequences. To date, we have not, however, received any requests for information or counselling.

Category 5. Asymptomatic partners (no family history) of carriers, tested as a control for prenatal diagnosis. A couple with one parent carrier of HD (43 repeats) applied for prenatal diagnosis. DNA analysis was also done on the healthy partner as a control (maternal contamination or homozygosity). The fetus showed a normal and an intermediate (31) repeat, the latter inherited from the healthy partner. The risk of the fetus developing HD is small. In future pregnancies of this couple or of the unborn child, there is a risk of expansion of the repeat in a disease allele. Also, there is a risk for relatives of the partner with the intermediate allele.

Intermediate alleles $(3.9 \%)$ and reduced penetrance alleles $(2.5 \%)$ were encountered in 71 of 1101 persons, affected and unaffected, from 42 different families. The frequency of intermediate (together with a disease/reduced penetrance allele) and reduced penetrance alleles in our symptomatic population $(n=659)$ is $2.6 \%$ and $2.4 \%$, respectively, and the frequency of intermediate and reduced penetrance alleles in asymptomatic test applicants $(\mathrm{n}=442)$ is $5.8 \%$ and $2.7 \%$, respectively. The frequency of intermediate alleles $(3.9 \%)$ is significantly higher $(p=0.002-0.004)$ than previously reported $(1.5-1.9 \%)^{6}{ }^{15}$ in the general population, because the intermediate allele range has increased (currently 27 to 35 repeats as opposed to 30 to $35^{6}$ or 29 to $35^{15}$ repeats) and also intermediate alleles of relatives of newly identified patients (4th category) who became predictive test applicants are included in our series. Intermediate alleles (mean repeat length 29) in asymptomatic and symptomatic (besides a disease allele) test applicants, inherited from the unaffected family branch, were most frequent (46\%). Reduced penetrance alleles in symptomatic test applicants (mean repeat length 39) were also quite frequent (22\%). No symptomatic test applicants with an intermediate allele only were detected. Categories 4 and 5 were infrequently encountered $(11 \%)$ and only intermediate alleles were found (table 1). Fourteen of the 43 intermediate test results $(33 \%)$ were smaller than 30 CAG repeats and analysed before 1998, when the limit of the intermediate repeat was considered 30 repeats. These carriers were not informed when the limit was set at 27 repeats. Only a few unaffected adult children of parents without a family history and a repeat between 27 and $39(n=3)$, unaffected parents of children carrying more than 27 repeats without a family history $(n=6)$, and sibs of newly identified patients $(n=8)$ requested testing, but no other relatives (for example, sibs or nieces/nephews of the unaffected parent with an intermediate or reduced penetrance allele). Only one female carrier of an intermediate allele on the HD haplotype requested a prenatal test.

Since the identification of the mutation leading to HD, DNA analysis has been useful for confirming the clinical diagnosis and for predictive and prenatal testing. However, in asymptomatic subjects, the size of the CAG repeat, through its natural property of variability in transmission, may in a few percent be of a class where a straightforward prediction of the phenotype or future disease is not possible. The cases described (fig 1) illustrate the counselling problems associated with an intermediate or reduced penetrance allele.

Identification of HD disease status (by family history, pathology, and DNA data) of relatives in a family is of paramount importance. Family members who may have (had) physical or mental complaints that went unnoticed because they were not admitted to hospital, under medical surveillance, or were misdiagnosed, should be re-evaluated.

Sometimes it is necessary to perform additional investigations (for example, DNA analysis, neurological/ psychiatric examination) in the parent without a family history for interpretation of an intermediate or reduced penetrance allele found in the applicant. Knowing whether there are HD patients, (a)symptomatic carriers of reduced penetrance alleles, or carriers of intermediate alleles in the family may have implications for counselling.

It is important to inform applicants in pre-test sessions about repeat lengths, the possible uncertainties in a few percent of predictive, diagnostic, or prenatal tests related to the nature of the repeat mechanism, and the chance of intermediate or reduced penetrance alleles. Although it is possible in pre-test sessions to explore the desire to know these uncertain test results, it can be debated whether in the complex process of decision making the discussion about risks for expansion and penetrance should be allowed.

The limits of the different categories of the repeat size have changed in time, ${ }^{79}{ }^{182526}$ so normal results may have changed to intermediate, intermediate to reduced penetrance, and disease to reduced penetrance alleles. Furthermore, the initial analysis included a CCG repeat downstream, which was later proven to be polymorphic. ${ }^{31}$ This may have had consequences for those carrying borderline sized repeats. In addition, the data currently available do not yet allow us to provide exact penetrance risk figures for those who received a disease or an interme- 
Table 2 Provisional additional guidelines for counselling (possible) carriers of intermediate and reduced penetrance alleles of Huntington's disease

Pre-test information

Family history (neurological/psychiatric examination, DNA data, pathology)

Four ranges of repeat sizes

Chance of unexpected test results

Uncertainties about risk of expansion of intermediate alleles and penetrance of disease alleles with reduced penetrance

Difference of intermediate test result for sons and daughters

Chance of additional investigation of the unaffected parent without a family history for interpretation of the intermediate or reduced penetrance allele found in the applicant

Exploration of the wish to know an intermediate or reduced penetrance allele test result

Disclosure of repeat size if CAG repeat size is between 27 and 39

Offering the possibility of information and predictive testing to relatives of carriers with repeats between 27 and 39 (after adjusting to the awareness of what it means to be at risk)

Discussing the possibility of prenatal testing with carriers with repeats between 27 and 39 because of the as yet unknown risk of expansion and penetrance

Psychological support in decision making, before and after testing for applicant and relatives if they so wish

diate allele (especially those without a family history), which we now call reduced penetrance alleles. Nor are we able to give exact risk figures for expansions to those (especially those without a family history) who received a normal test result, which we now call intermediate alleles. In these "minimal risk" situations, for example, when unaffected parents or partners without a family history are involved, it might be wise to refrain from providing information $^{32}$ or retesting.

Our policy with regard to disclosing results is not to communicate the repeat length unless applicants ask for it. ${ }^{33}$ In the case of intermediate or reduced penetrance alleles, we are specific about the repeat length, because of the possible consequences for applicants, offspring, and relatives.

In our opinion, adult children of carriers of intermediate repeats can be informed by their parents and the possibility of predictive testing can be offered because of the as yet unknown risk of expansion. It can be asked whether it is morally justified and good medical practice to burden other relatives, especially those families without a HD patient, with these uncertain risks for a disorder with which they are not familiar. On the other hand, not informing might prevent people from making decisions concerning their life and future. Admittedly, the risk of an intermediate allele is much less than that of a HD disease allele, but subjects and families may want to reconsider their risks. It remains to be seen whether and how they cope with the new consideration, information, and situation. Informing relatives of carriers of reduced penetrance alleles (by the carriers) and offering the option of predictive testing is hardly under debate because this risk approximates the risk of a disease allele carrier.

It should be borne in mind that a prenatal test always carries a risk for a pregnancy and that prenatal testing for HD has been used by only a minority of at risk subjects ( $2 \%$ of those under the age of 50$)$ and asymptomatic disease allele carriers $(11 \%) .{ }^{34}$ We are of the opinion that the option of prenatal testing for intermediate allele carriers can be discussed because of the as yet unknown risk of expansion. Prenatal testing for this indication resembles prenatal testing for a chromosomal translocation with a small risk of unbalanced offspring or chromosomal abnormalities in women over 36 years. We have not yet received a request for termination of a fetus carrying an intermediate allele, with a small risk $(<1 \%)$ of developing HD but with an unknown risk for future generations. Even if the penetrance is considered to be complete, only $1 / 2$ of the at risk subjects would accept a pregnancy termination for HD. ${ }^{29}$ Although no empirical risk figures exist yet, prenatal testing for carriers of reduced penetrance alleles can be an option because of the possibility of penetrance.

Specific psychological problems were seen in subjects who decided to be tested in the hope of relieving their children of the risk of HD and unexpectedly were found to have an intermediate repeat. While receiving a decreased risk themselves, they may have to tell their children that they have not yet escaped HD, as there is still a risk for expansion with a risk for them or the next generations. The parents and children do not share a common fate, as is usual in dominant disorders, which can result in sustained feelings of guilt in the parents and reproach in the children, as in recessive disorders.

Other problems concern the difficulty in coping with the uncertainty about the risk of expansion and penetrance, the difference of an intermediate test result for daughters and sons, and turmoil induced by informing relatives, unaware of a risk, about the uncertain consequences of intermediate and reduced penetrance alleles. Besides this, it is important to realise that it is difficult for most of these applicants, who are unexpectedly confronted with a risk for themselves, their offspring, and relatives to live with this uncertainty. It is our experience that most applicants, and especially this group, not familiar with HD and testing, wish to know the result as soon as possible, to restore control over their life. This is an understandable reaction to a far reaching event, but may lead to underestimation of the ramifications of testing. It is therefore recommended that these subjects especially first become fully aware of what it means to be at risk and to adjust to this awareness. Then, testing could be an option.

Wilson Harvey wrote in 1657 "there is no better way to advance to proper practice of medicine than to give our minds to the discovery of the usual law of Nature by careful investigation of rarer forms of disease", which is particularly pertinent for this repeat expansion disorder. ${ }^{8}$ It is a new challenge to carry out this next phase in the Huntington story, because HD has been a kind of paradigm for late onset hereditary diseases. We propose that the international guidelines, ${ }^{28}$ not mentioning anything about intermediate and reduced penetrance alleles, should be adapted and that with help of further research and experience these provisional guidelines (table 2) should be improved.

We wish to thank Prof Dr R A C Roos for critical reading the manuscript, Drs $M$ Vegter-van der Vlis, P Helderman, and S Kant for information about the cases, Dr A H Zwinderman for statistical assistance, and Dr R Giles for language editing.

ANNEKE MAAT-KIEVIT ${ }^{\star}+$ MONIQUE LOSEKOOT ${ }^{\star}+$ HANNEKE VAN DEN BOER-VAN DEN BERG ${ }^{\star}+\Phi$ GERT-JAN VAN OMMEN $\ddagger$ MARTINUS NIERMEIJER $\dagger$ MARTIJN BREUNING* AAD TIBBEN+ף **

${ }^{\star}$ Department of Clinical Genetics, Leiden University Medical Centre, PO Box 9600, 2300 RC Leiden, The Netherlands

†Department of Clinical Genetics, Erasmus University Medical Centre Rotterdam, Rotterdam, The Netherlands

$\ddagger$ Department of Human Genetics, Leiden University Medical Centre, Leiden, The Netherlands

$\$$ Department of Philosophy, Medical Ethics, and History of Medicine, Erasmus University Medical Centre Rotterdam, Rotterdam, The Netherlands 
\Department of Neurology, Leiden University Medical Centre, Leiden, The Netherlands

${ }^{\star} \star$ Department of Medical Psychology, Erasmus University Medical Centre Rotterdam, Rotterdam, The Netherlands

Correspondence to: Dr Maat-Kievit, J.A.Maat@KGC.AZL.NL

1 Roos RAC, Hermans J, Vegter-vd Vlis M, van Ommen GJB, Bruyn GW. Duration of illness in Huntington's disease is not related to age at onset. $\mathcal{F}$ Duration of illness in Huntington's disease is
Neurol Neurosurg Psychiatry 1993;56:98-100.

2 Harper PS. Huntington's disease. London: Saunders, 1996.

2 Harper PS. Huntington's disease. London: Saunders, 1996. Gusella JF, Wexler NS, Conneally PM Naylor SL, Anderson MA, Tanzi RE,
Watkins PC, Ottina K, Wallace MR, Sakaguchi AY, Young AB, Shoulson I, Bonilla E, Martin JB. A polymorphic DNA marker genetically linked to Huntington's disease. Nature 1983;306:234-8.

4 Wiggins S, Whyte P, Huggins $M$. The psychological consequences of predictive testing for Huntington disease. Canadian Collaborative Study of Predictive Testing. N Engl F Med 1992;327:1401-5.

5 Huntington Disease Collaborative Research Group. A novel gene containing a trinucleotide repeat that is expanded and unstable on Huntington's disease chromosomes. Cell 1993;72:971-83.

6 Kremer B, Goldberg YP, Andrew SE, Theilmann J, Telenius H, Zeisler J, Squittieri F, Lin B, Bassett A, Almqvist E, Bird TP, Hayden MR. A worldwide study of the Huntington's disease mutation: the sensitivity and specificity of measuring CAG repeats. N Engl F Med 1994;330:1401-6.

7 Rubinsztein DC, Leggo J, Coles R, Almqvist E, Biancalana V, Cassiman JJ, Chotai K, Connarty M, Craufurd D, Curtis A, Curtis D, Davidson MJ, Differ AM, Dode C, Dodge A, Frontali M, Ranen NG, Stine OC, Sherr M, Abbott MH, Franz MC, Graham CA, Harper PS, Hedreen JC, Jackson A, Abbott MH, Franz MC, Graham CA, Harper PS, Hedreen JC, Jackson A,
Kaplan JC, Losekoot M, MacMillan JC, Morrison P, Trottier Y, Noveletto Kaplan JC, Losekoot M, MacMillan JC, Morrison P, Trottier Y, Noveletto A, Simpson SA, Theilmann J, Whittaker JL, Folstein SE, Ross CA, Hayden MR. Phenotypic characterization of individuals with 30-40 CAG repeats in
the Huntington disease gene reveals Huntington disease cases with 36 the Huntington disease gene reveals. Huntington disease cases with 36 Hum Genet 1996;59:16-22

8 Andrew SE, Goldberg YP, Hayden MR. Rethinking genotype and phenotype correlations in polyglutamine expansion disorders. Hum $\mathrm{Mol}$ Genet 1997;6:2005-10.

9 American College of Medical Genetics/American Society of Human Genetics Huntington Disease Genetic Testing Working Group. Laboratory
guidelines for Huntington disease genetic testing. Am $\mathcal{F}$ Hum Genet 1998;62:1243-7.

10 Duyao M, Ambrose C, Myers R, Noveletto A, Persichetti F, Frontali M, Folstein S, Ross C, Franz M, Abbott M, Gray J, Conneally P, Young A, Penney J, Hollingsworth Z, Shoulson I, Lazzarini A, Falek A, Korshetz W, Sax D, Bird E, Vonsattel J, Bonilla E, Alvir J, Bickham Conde J, Cha JH, Dure L, Gomez F, Ramos M, Sanchez-Ramos J, Snodgrass S, de Young M, Wexler N, Moscowitz C, Penchaszadeh G, MacFarlane H, Anderson M, Jenkins B, Srinidhi J, Barnes G, Gusella J, MacDonald M. Trinucleotide Jenkins B, Srinidhi J, Barnes G, Gusella J, MacDonald M. Trinucleotide repeat length: instability

11 Benjamin CM, Adam S, Wiggins S, Theilmann JL, Copley TT, Bloch M, Squitieri F, McKellin W, Cox S, Brown SA, Kremer HPH, Burgess M, Meshino W, Summers A, Macgregor D, Buchanan J, Greenberg C, Carson N, Ives E, Frecker M, Welch JP, Fuller A, Rosenblatt D, Miller S, Dufrasne S, Roy M, Andermann E, Prevost C, Khalifa M, Girard K, Taylor S, Hunter A, Goldsmith C, Whelan D, Eisenberg D, Soltan H, Kane J, Shokeir MHK, Gibson A, Cardwell S, Bamforth S, Grover S, Suchowersky O, Klimek M, Garber HA, Macleod P, Hayden MR. Proceed with care: direct testing for Huntington disease. Am F Hum Genet 1994;55:606-17.

12 Leeflang EP, Zhang L, Tavare S, Hubert R, Srinidhi J, MacDonald ME, Myers RH, de Young M, Wexler NS, Gusella JF, Arnheim N. Single sperm analysis of the trinucleotide repeats in the Huntington's disease gene: quantification of the mutation frequency spectrum. Hum Mol Genet 1995; 4:1519-26.

13 Telenius H, Almqvist E, Kremer B, Spence N, Squitieri F, Nichol K, Grandell U, Starr E, Benjamin C, Castaldo I, Calabrese O, Anvret M, Goldberg
YP, Hayden MR. Somatic mosaicism in sperm is associated with intergenYP, Hayden MR. Somatic mosaicism in sperm is associated with intergen-
erational (CAG)n changes in Huntington disease. Hum Mol Genet 1995;4: 189-95.

14 Chong SS, Almqvist E, Telenius H, LaTray L, Nichol K, Bourdelat-Parks B, Goldberg YP, Haddad BR, Richards F, Sillence D, Greenberg CR, Ives E, Van den Engh G, Hughes MR, Hayden MR. Contribution of DNA sequence and CAG size to mutation frequencies of intermediate alleles for Huntington disease: evidence from single sperm analyses. Hum $\mathrm{Mol}$ Genet 1997;6:301-9.

15 Goldberg YP, McMurray CT, Zeisler J, Almqvist E, Sillence D, Richards F, Gacy AM, Buchanan J, Telenius H, Hayden MR. Increased instability of intermediate alleles in families with sporadic Huntington disease compared to similar sized intermediate alleles in the general population. Hum Mol Genet 1995;4:1911-18

16 Goldberg YP, Kremer B, Andrew SE, Theilmann J, Graham RK, Squitieri F, Telenius H, Adam S, Sajoo A, Starr E, Heiberg A, Wolff G, Hayden MR. Molecular analysis of new mutations for Huntington's disease: intermediate alleles and sex of origin effects. Nat Genet 1993;5:174-9.

17 Myers RH, MacDonald ME, Koroshetz WJ, Duyao MP, Ambrose CM, Taylor SA, Barnes G, Srinidhi J, Lin CS, Whaley WL, Lazzarini AM, Schwarz M, Wolff G, Bird ED, Vonsattel JPG, Gusella JF. De novo expansion of a (CAG)n repeat in sporadic Huntington's disease. Nat Genet 1993; 5:168-73.

18 McGlennan RC, Allinson PS, Matthias-Hagen VL, Parker TL, Lovell MA, Kelley TE. Evidence of an unstable paternal 27 CAG repeat allele in the huntingtin gene giving rise to clinically overt Huntington disease in a patient with the genotype (17/38). Am f Hum Genet 1995; suppl 57:A246.

19 Zuhlke C, Riess O, Bockel B, Lange H, Thies U. Mitotic stability and meiotic variability of the (CAG)n repeat in the Huntington disease gene. Hum Mol Genet 1993;2:2063-7.

20 Kremer B, Almqvist E, Theilmann J, Spence N, Telenius H, Goldberg YP, Hayden MR. Sex-dependent mechanisms for expansions and contractions of the CAG repeat on affected Huntington disease chromosomes. $A m \mathcal{F}$ Hum Genet 1995;57:343-50.

21 Montermini L, Andermann E, Labuda M, Richter A, Pandolfo M, Cavalcanti F, Pianese L, Iodice L, Farina G, Monticelli A, Turano M, Filla A, De Michelle G, Cocozza S. The Friedreich ataxia GAA triplet repeat: premutation and normal alleles. Hum Mol Genet 1997;6:261-6.

22 Imbert G, Kretz C, Johnson K, Mandel JL. Origin of the expansion mutation in myotonic dystrophy. Nat Genet 1993;4:72-6.

23 Stevanin G, Giunti P, Belal GDS, Durr A, Ruberg M, Wood N, Brice A. De novo expansion of intermediate alleles in spinocerebellar ataxia 7. Hum Mol Genet 1998;7:1809-13.

24 Murray A, Macpherson JN, Pound M, Sharrock A, Youings NR, McKechnie N, Linehan P, Morton NE, Jacobs PA. The role, the size, sequence and haplotype in the stability of FRAXA and FRAXE alleles during transmission. Hum Mol Genet 1997;6:173-84.

25 Legius E, Cuppens $H$, Dierick $H$, Van Zandt K, Dom R, Frijns JP, Evers-Kieboom G, Decruyenaere M, Demyttenaere K, Marynen P, Cassiman JJ. Limited expansion of the (CAG)n repeat of the Huntington gene: a premutation? Eur f Hum Genet 1994;2:44-50.

26 McNeil SM, Novolletto A, Srinidhi J, Barnes G, Kornbluth I, Altherr MR, Wasmuth JJ, Gusella JF, MacDonald ME, Myers RH. Reduced penetrance of the Huntington's disease mutation. Hum Mol Genet 1997;6:775-9.

27 Brinkman RR, Mezei MM, Theilmann J, Almqvist E, Hayden MR. The likelihood of being affected with Huntington disease by a particular age, for a specific CAG size. Am ₹ Hum Genet 1997;60:1202-10.

28 International Huntington Association and World Federation of Neurology Research Group on Huntington's Chorea. Guidelines for the molecular genetics predictive test in Huntington's disease. F Med Genet 1994;31:5559.

29 Tibben A, Frets PG, vd Kamp JJP, Niermeyer MF, Vegter-vd Vlis M, Roos RA, van Ommen GJ. Presymptomatic DNA testing for HD: pretest attitudes and expectations of applicants and their partners in the Dutch program. Am F Med Genet 1993;48:10-61.

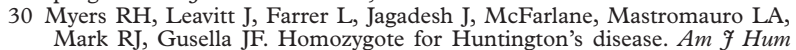
Genet 1989;45:615-18.

31 De Rooy KE, de Koning Gans PAM, Losekoot M, Bakker B, Den Dunnen $J T$, Vegter-vd Vlis R, Roos R, van Ommen GJB. Borderline repeat expansions in Huntington's disease. Lancet 1993;342:1491-2.

32 Van den Boer-van den Berg HMA, Maat-Kievit AA. The whole truth and nothing but the truth, but what is the truth? F Med Genet 2001;38:39-42.

33 Burgess MM, Hayden MR. Patient's right to laboratory data: trinucleotide repeat length in Huntington disease. Am 7 Med Genet 1996;62:6-9.

34 Maat-Kievit JA, Vegter van der Vlis M, Zoeteweij M, Losekoot M, van Haeringen A, Roos RAC. Experience in prenatal testing for Huntington's disease in The Netherlands: procedures, results and guidelines. Prenat Diagn 1989;19:450-7. 